\title{
Marine Algae as a Precursor for Eco-Friendly Synthesis of
}

\section{Nanoparticles}

\begin{abstract}
Sally A El Zahaby*
Department of Pharmaceutics \& Pharmaceutical Technology, Faculty of Pharmacy \& Drug Manufacturing, Pharos University in Alexandria, Alexandria, Egypt
\end{abstract}

*Corresponding author: Sally A El-Zahaby, Department of Pharmaceutics \& Pharmaceutical Technology, Faculty of Pharmacy \& Drug Manufacturing, Pharos University in Alexandria, Alexandria, Egypt, Email: sally.elzahaby@yahoo.com

\section{Editorial}

Volume 2 Issue 4

Received Date: December 03, 2018

Published Date: December 10, 2018 DOI: $10.23880 /$ oajpr-16000167

\section{Editorial}

In the last decade, researchers were developing different types of nanoparticles and exploring more and more applications that made this area of research so promising and very active. Actually, many techniques can be followed in order to prepare nanoparticles. Usually either physical or chemical methodologies were applied. Nowadays, biological methods are very fast growing, moving the synthesis of nanoparticles towards more safe and eco-friendly way of production in addition of being cost effective. Although the chemical methods were used in majority of researches, they had many drawbacks; toxic chemicals are usually used, high cost of reagents, and multi-steps preparation methods [1,2]. Even physical methods were expensive to apply and their yields were too small compared to the high energy consumed in the preparation procedures. On the other hand, using biological precursors for nanoparticles synthesis like; reduction of metal ions using algae extract, had helped avoiding all the aforementioned problems of both chemical and physical methods [3]. The algae acted as nano-factories for the synthesis of different metal nanoparticles. In this regard, many researchers had developed production methodologies; gold nanoparticles (AuNPs) were prepared using different types of marine brown algae extracts (Kappaphycus alvarezii, Stoechospermum marginatum and Laminaria japonica) and the yield was promising where spherical AuNPs of average size $31 \mathrm{~nm}$ were produced [4]. Additionally, Shewanella algae was used to formulate AuNPs, herein, the algae acted as reducing agent in addition of being shape-controlling agent. The preparation method was single-step, involved reduction of aqueous $\mathrm{Au} \mathrm{Cl}_{4}$ - ions with no $\mathrm{pH}$ adjustment and even at room-temperature and produced high yield of AuNPs [5]. They could be used as diagnostic tool and as anti-cancer agents [6]. In another study, Silver nanoparticles (AgNPs) were synthesized using ethanol extract of Marine Red Algae (Acanthophora spicifera), the produced AgNPs had size range of 33-81 $\mathrm{nm}[7,8]$. An extract of the brown marine algae Cystophora moniliformis acted as both a reducing and stabilising agent for producing AgNPs of average size $75 \mathrm{~nm}$. The marine algae Caulerpa racemosa was also used to produce AgNPs of size ranged from 5 to $25 \mathrm{~nm}$. The AgNPs were found to be stabilized by proteins present in the marine algae extract which acted as capping agent for the nanoparticles [9]. The AgNPs can act as antimicrobial agents thus resolve the problem of antibiotic resistance that became a major problem worldwide [10]. Zinc oxide (ZnO) nanoparticles were also prepared eco-friendly using Gracilaria edulis (GE) algae extract and it was found to have anticancer activity against human prostate cancer cell lines [11]. The abovementioned eco-friendly methods for producing different metal nanoparticles presented simple, low cost, high yield green procedure that helped in avoiding any hazardous by-products of chemical synthesis and thus safer environment. All these promising outcomes are very challenging to researchers to continue exploring the capabilities of different algae in production of diverse types of metals nanoparticles.

\section{References}

1. Li Y, Duan X, Qian Y, Yang L, Liao H (1999) Nanocrystalline silver particles: synthesis, 


\section{Open Access Journal of Pharmaceutical Research}

agglomeration, and sputtering induced by electron beam. J Colloid Interface Sci 209(2): 347-349.

2. Tan Y, Dai X, Li Y, Zhu D (2003) Preparation of gold, platinum, palladium and silver nanoparticles by the reduction of their salts with a weak reductantpotassium bitartrate. Journal of Materials Chemistry 13(5): 1069-1075.

3. Albrecht MA, Evans CW, Raston CL (2006) Green chemistry and the health implications of nanoparticles. Green chemistry 8(5): 417-432.

4. Ramakrishna M, Babu DR, Gengan RM, Chandra S, Rao GN (2016) Green synthesis of gold nanoparticles using marine algae and evaluation of their catalytic activity. Journal of Nanostructure in Chemistry 6(1): 1-13.

5. Ogi T, Saitoh N, Nomura T, Konishi Y (2010) Roomtemperature synthesis of gold nanoparticles and nanoplates using Shewanella algae cell extract. Journal of Nanoparticle Research 12(7): 2531-2539.

6. Parial D, Patra HK, Dasgupta AK, Pal R (2012) Screening of different algae for green synthesis of gold nanoparticles. European journal of phycology 47(1): 22-29.
7. Ibraheem I, Abd-Elaziz B, Saad W, Fathy W (2016) Green biosynthesis of silver nanoparticles using marine Red Algae Acanthophora specifera and its antimicrobial activity. J Nanomed Nanotechnol 7(6): 1-4.

8. Merin DD, Prakash S, Bhimba BV (2010) Antibacterial screening of silver nanoparticles synthesized by marine micro algae. Asian Pacific Journal of Tropical Medicine 3(10): 797-799.

9. Kathiraven T, Sundaramanickam A, Shanmugam N, Balasubramanian T (2015) Green synthesis of silver nanoparticles using marine algae Caulerpa racemosa and their antibacterial activity against some human pathogens. Applied Nanoscience 5(4): 499-504.

10. Kumar A, Vemula PK, Ajayan PM, John G (2008) Silvernanoparticle-embedded antimicrobial paints based on vegetable oil. Nature materials 7(3): 236-241.

11. Priyadharshini RI, Prasannaraj G, Geetha N, Venkatachalam P (2014) Microwave-mediated extracellular synthesis of metallic silver and zinc oxide nanoparticles using macro-algae (Gracilaria edulis) extracts and its anticancer activity against human PC3 cell lines. Appl Biochem Biotechnol 174(8): 2777-2790. 